\title{
Handbook of Florida Water Regulation: Florida Department of Agriculture and Consumer Services ${ }^{1}$
}

\author{
Michael T. Olexa, Luke D'Isernia, Laura Minton, Dulcy Miller, and Sarah Corbett ${ }^{2}$
}

\section{Preface}

This handbook is designed to provide an accurate, current, and authoritative summary of the principle Federal and Florida laws that directly or indirectly relate to agriculture. This handbook should provide a basic overview of the many rights and responsibilities that farmers and farmland owners have under both Federal and Florida laws as well as the appropriate contact information to obtain more detailed information. However, the reader should be aware that because the laws, administrative rulings, and court decisions on which this handbook is based are subject to constant revision, portions of this publication could become outdated at anytime.

Several details of cited laws are also left out due to space limitations.

This handbook is distributed with the understanding that the authors are not engaged in rendering legal or other professional advice, and the information contained herein should not be regarded as a substitute for professional advice. This handbook is not all inclusive in providing information to achieve compliance with the Federal and Florida laws and regulations governing water protection. For these reasons, the use of these materials by any person constitutes an agreement to hold harmless the authors, the Florida Cooperative Extension Service, the Institute of Food and Agricultural Sciences, and the University of Florida for any liability claims, damages, or expenses that may be incurred by any person as a result of reference to or reliance on the information contained in this handbook.

\section{Overview}

The Florida Department of Agriculture and Consumer Services (DACS) carries out functions related to farming practices and products such as ensuring the safety and wholesomeness of food and other consumer products through inspection and testing programs; assisting Florida's farmers and agricultural industries with the production and promotion of agricultural products; and conserving and protecting the state's agricultural and natural resources by reducing wildfires, promoting

1. This is EDIS document FE596, a publication of the Food and Resource Economics Department, Florida Cooperative Extension Service, Institute of Food and Agricultural Sciences, University of Florida, Gainesville, FL. Published December 2005. Please visit the EDIS website at http://edis.ifas.ufl.edu.

2. Michael T. Olexa, Professor, Food and Resource Economics Department, Florida Cooperative Extension Service, Institute of Food and Agricultural Sciences, University of Florida, Gainesville, FL; Director, Agricultural Law Center, University of Florida, Gainesville, FL; and Chair, Agricultural Law Committee of The Florida Bar. Luke D'Isernia, former student (graduated cum laude in 2005), Levin College of Law, University of Florida, Gainesville, FL. Laura Minton, Attorney, Dean, Mead, Egerton, Bloodworth, Capouano, and Bozarth, Orlando, FL. Dulcy Miller, attorney, Foley and Lardner, LLP, Orlando, FL. Sarah Corbett, Attorney, Florida Second District Court of Appeal, Lakeland, FL.

The Institute of Food and Agricultural Sciences (IFAS) is an Equal Opportunity Institution authorized to provide research, educational information and other services only to individuals and institutions that function with non-discrimination with respect to race, creed, color, religion, age, disability, sex, sexual orientation, marital status, national origin, political opinions or affiliations. U.S. Department of Agriculture, Cooperative Extension Service, University of Florida, IFAS, Florida A. \& M. University Cooperative Extension Program, and Boards of County Commissioners Cooperating. Larry Arrington, Dean 
environmentally safe agricultural practices, and managing public lands. Responsibilities include:

- The registration, labeling, and inspection of commercial fertilizers, pesticides, and gasoline and oils.

- The registration (i.e., licensing and regulation) of pesticide applicators.

- Soil and water conservation.

DACS is divided into nineteen divisions, each with a separate concern, as illustrated in the following four divisions:

\section{- Division of Agricultural and Environmental}

Services regulates and licenses pest control operators and provides assistance to the Soil and Water Conservation Districts. Within this division is the Bureau of Pesticides which registers pesticides sold and used in the state and oversees pesticide programs that are related to the protection of public health and the environment. The Bureau of Entomology and Pest Control which protects the health and safety of Florida's consumers and environment through effective mosquito control and pest control regulation. It also assists in assuring compliance with the Federal Insecticide, Fungicide, and Rodenticide Act under a cooperative agreement with the EPA. The Bureau of Feed, Seed \& Fertilizer Laboratories which, through its feed and seed programs, tests samples of feed and seed to ensure that consumers receive quality products, to provide a level playing field for all manufacturers, and to promote environmental stewardship.This division also includes the Bureau of Soil and Water Conservation.

- Division of Standards is responsible, through its Bureaus of Fair Rides Inspection (http://www.doacs.state.fl.us/standard/fairs/ index.html), Liquified Petroleum Gas Inspection (http://www.doacs.state.fl.us/standard/lpgas/ index.html), Petroleum Inspection (http://www.doacs.state.fl.us/standard/petro/ index.html), and Weights and Measures Inspection (http://www.doacs.state.fl.us/standard/weights/ index.html), for the protection of consumers from unfair and unsafe business practices across a wide range of products, including gasoline, brake fluid, antifreeze, liquefied petroleum gas, amusement rides, and weighing and measuring devices.

- Division of Forestry manages forest resources. Within this division is the Bureau of Planning Services which includes the Watershed Protection Section (WPS). The WPS offers professional hydrology (water-use science) services to the public and other state agencies. It is also responsible for developing the silviculture (forestry) elements of the State Water Quality Plan (see FE594, Water Management Districts). Most important, the WPS monitors impacts of water regulation on forestry and could be most helpful in assisting the farmer in managing any forest resources that he might possess.

- Division of Administration handles the administrative functions of the Florida Department of Agriculture and Consumer Services. This division includes the Office of Agricultural Law Enforcement, which provides for the inspection of agricultural products. It also includes the Bureaus of Finance and Accounting, General Services, Personnel Management, Planning and Budgeting, Training and Development, and the Agriculture Management Information Center.

DACS also includes the Office of Agricultural Water Policy (OAWP) which provides for communication among federal, state, and local agencies, and the agricultural industry on water quantity and water quality issues involving agriculture. The OAWP is actively involved in the development of Best Management Practices (BMP), addressing both water quality and water conservation on a site specific, regional, and watershed basis.

\section{Acknowledgments}

The authors are indebted to the personnel of both state and federal agencies who provided their time and advice in the preparation of this handbook. The authors are especially indebted to Richard Budell of the Office of Agricultural Water Policy of the Florida Department of Agriculture and Consumer Services 
for providing funds for the development of this publication. 